\title{
Título da página electrónica: Project Censored
}

Endereço: http://www.projectcensored.org/index.html

José Manuel Mendes

\section{(2) OpenEdition}

\section{Journals}

Edição electrónica

URL: http://journals.openedition.org/rccs/1365

DOI: $10.4000 /$ rccs. 1365

ISSN: 2182-7435

\section{Editora}

Centro de Estudos Sociais da Universidade de Coimbra

Edição impressa

Data de publição: 1 outubro 2004

Paginação: 171

ISSN: 0254-1106

Refêrencia eletrónica

José Manuel Mendes, «Título da página electrónica: Project Censored », Revista Crítica de Ciências Sociais [Online], 69 | 2004, posto online no dia 01 outubro 2012, consultado o 22 setembro 2020. URL: http://journals.openedition.org/rccs/1365; DOI : https://doi.org/10.4000/rccs.1365 


\section{Espaço Virtual}

\section{Título da página electrónica: Project Censored Endereço: http://www.projectcensored.org/index.html}

Esta página é coordenada por Peter Philips e é produzida por uma vasta equipa de activistas da Sonoma State University, California. Tem como objectivo principal proceder a uma análise crítica e alternativa do campo mediático nos Estados Unidos, salientando o papel crucial do jornalismo independente no contexto norte-americano. Todos os anos é publicado o relatório Censored, onde se apresenta de forma exaustiva 25 notícias que, apesar da sua relevância, não foram abordadas pelos meios de comunicação dominantes.

Embora esta página disponibilize poucos recursos gratuitos, permite o acesso a resumos do seus relatórios desde o ano 2000 e possui uma excelente lista de ligações relacionadas com os temas do jornalismo, da democracia e dos movimentos anti-globalização.

A página está bem desenhada e é de fácil acesso. A excessiva concentração em problemáticas relacionadas exclusivamente com os meios de comunicação nos Estados Unidos é o ponto mais fraco, mas a página não deixa de ser um recurso importante para o estudo do papel dos media nas sociedades contemporâneas.

\section{Título da página electrónica: Página Pessoal de Douglas Kellner Endereço: http://www.gseis.ucla.edu/faculty/kellner/kellnerhtml.html}

Esta é a página pessoal de Douglas Kellner, Professor aa Universidade da California, Los Angeles. Reconhecido como um especialista no estudo da cultura de massas e reivindicando-se de uma teoria crítica, directamente na esteira da Escola de Frankfurt, Douglas Kellner tem contribuído nos últimos anos para uma reflexão crítica sobre o sistema de poder norte-americano e a importância dos meios de comunicação social na reprodução e legitimação do mesmo.

A página apresenta cinco secções principais: ligações de interesse; livros; artigos; visões alternativas e audio/video. Saliente-se, na secção de livros, uma edição electrónica sobre as eleições norte-americanas deste ano, bem como a disponibilização de extractos das suas obras mais relevantes. Nos artigos, saliente-se aqueles que dialogam com as propostas de Jean Baudrillard, de Herbert Marcuse e também os que abordam criticamente as teorias da globalização e o seu impacto nos media. Especial menção merece o artigo sobre o filme $A$ Paixão de Cristo de Mel Gibson, um exercício lúcido de desconstrução narrativa.

A parte mais inovadora da página prende-se com o projecto Visões Alternativas, em parceria com Frank Morrow, sobre a capacidade da televisão por cabo para transmitir perspectivas diferenciadas e críticas a nível nacional e internacional. A secção Audio e Video contém documentos importantes sobre alguns autores da teoria crítica, como Herbert Marcuse e Ivan Illich.

A página tem um desenho moderno e arrojado, sendo, contudo, de fácil navegação. Pelos conteúdos apresentados, constitui um das páginas mais importantes na área dos estudos da comunicação e da teoria crítica. 


\section{Título da página electrónica: Social Movements International Network/Red Internacional de los Movimientos Sociales Endereço: http://www.movsoc.org/index.htm}

No âmbito do Fórum Social Mundial, foi criada a Rede Internacional de Movimentos Sociais, com sede em São Paulo. Esta é a página dessa Rede, que congrega um vasto conjunto de movimentos sociais de diferentes países que têm como objectivo principal a luta contra a globalização neoliberal e todas as formas de opressão e exploração a nível mundial.

A página apresenta-se em edição bilingue, em inglês e espanhol, e abre com as conclusões dos encontros internacionais realizados e com a agenda da Rede. De referir o importante artigo de Eric Toussaint sobre o papel do Banco Mundial e do FMI na geoestratégia do capitalismo nos séculos XX e XXI.

Além de várias ligações de interesse, síntese de documentos e declarações, podemos obter textos e artigos sobre temáticas relacionadas com as lógicas e as dinâmicas dos movimentos sociais, sobretudo na América Latina. A pouca presença de textos de reflexão teórica e/ou crítica é o aspecto menos positivo desta página.

A página está desenhada de forma pouco atractiva, embora a navegação se faça sem grandes complicações.

José Manuel de Oliveira Mendes jomendes@fe.uc.pt 